\title{
Electronic Communication
}

Anna Zalesińska, Dariusz Szostek

\section{Introduction}

Electronic communication is one of the key tools in LegalTech 1.0. Apart from digitalisation of resources, it was the first of LegalTech instruments used by lawyers. It underwent significant evolution over the span of years. Beginning from first simple e-mails, through attaching documents thereto, using Skype-like solutions, and then more advanced messengers, videoconferencing, e-hearings, saving data on a cloud, making such data available and sharing thereof, to Distributed Ledger Technology (DLT) and blockchain and, finally, the AI. We are on the verge of automation of the process, combination of data from various sources, including from Internet of Things (IoT) solutions, the ever-greater elimination of the human factor, and datafication of documents.

Lawyers, as well as such organisations as the courts, the public administration, and law offices, are at varying stages of digital expertise. Those range from very weak - where only the simplest solutions are used (even today, there happen to be European states in the territory of which one cannot communicate with a court in an electronic manner ${ }^{1}$ ), through mid-range (electronic communication only as a means for "transport" of documents - an early stage of LegalTech, access to certain information or documents through a website, and e-hearings substituted for a "traditional" court hearing), to automated systems using databases supported by algorithms, machine learning, or ever-more frequently entering the domain of AI, based on DLT and blockchain at the end. A few years ago, lawyers sent entire volumes of casefiles between themselves and the courts, the administration, etc. Today, this takes place in organisations with low digital expertise. Slowly, storing respective data (and not entire documents) in blockchain which technologically safeguards their authenticity, integrity and immutability becomes standard. At the same time, an adequately set level of access allows for the possibility of parallel work on

1 Poland is an example of one, as there is no possibility of filing briefs via electronic communication. 
data by many persons in many systems, including by automatic systems, with a guarantee that there is continuity of data and that such data is up-to-date.

We are past the stage of implementing the human-to-human (institution/organisation) electronic communication. We are faced with, or are at the stage of (depending on the digital expertise of a given organisation) implementing human-to-machine (human-to-algorithm) electronic communication, and machine-to-machine communication (where a human only oversees the data ex post). Putting it differently, we are at the stage of implementing LegalTech in the matter of communication.

That which we send has changed. Documents in standardised formats (doc, pdf, xml, etc) are still dominant in organisations with low digital expertise. In those more developed, we are looking at appropriately structured data, not necessarily in formats deemed hitherto to be "traditional" electronic documents. Algorithms are in no need of documents, but of appropriately described data. A contemporary document is not only a closed, secured structure (e.g. in a pdf format, signed with a qualified electronic signature), but is also can function on the basis of data entered into blockchain (certainty of data and the possibility of verifying back data), being an active document. This is allowed inter alia by the novel approach of the European Union to an electronic document and to its directly applicable definition following from Article 3(35) of the eIDAS Regulation ${ }^{2}$, according to which 'electronic document' means any content stored in electronic form, in particular text or sound, visual or audio-visual recording. Many scholars refer to the second part of that definition which unfortunately indicates only the examples of documents structured into commonly known formats. For the purposes of LegalTech 2.0, the first part of the definition - any content, stored or made available in any manner, and thus including multi-source data entered into DLT or blockchain, acquired either from a human or from equipment, the latter including Internet of Things (IoT) or Internet of Body (IoB $)^{3}$. A consequence of such an approach is not only the new construction of a document, but also a new manner of communication between lawyers - organisations/institutions and algorithms.

2 Regulation (EU) 910/2014 of The European Parliament and of the Council of 23 July 2014 on Electronic Identification and Trust Services for Electronic Transactions in the Internal Market and Repealing Directive 1999/93/EC L 257/73.

3 Internet of Body: devices combining a body (be it human or animal) with the Internet, inter alia in telemedicine. 


\section{Transmission of Data and Making Data Available}

The natural phenomenon occurring for many years in organisations, both those functioning in the private sector and those of the public sectors, was to transmit data ${ }^{4}$ between employees (internal communication) or between an organisation and third parties (external communication) $)^{5}$. Transmission in the case of "paper-based" communication, in such an instance understood more as a physical transfer of media containing such data, required presentation of the original in order to duplicate its contents (through transcription, copying or digitalisation), or the transfer of a copy.

4 Data construed as facts. Structured data constitute information. In everyday usage, the terms of "data" and "information" often are used interchangeably. A hierarchy of cognitive concepts is named a "pyramid" or hierarchy of knowledge/information (the so-called DIKW, from data, information, knowledge, and wisdom). Information is one of the fundamental factors affecting the making of a decision in an organisation. It also constitutes a basis of knowledge building for persons involved in the process of its acquisition and utilisation. Martin H. Frické, 'DataInformation-Knowledge-Wisdom (DIKW) Pyramid, Framework, Continuum', in Laurie A. Schintler and Connie L. McNeely (eds) Encyclopedia of Big Data (Springer 2018) <https://doi.org/10.1007/978-3-319-32001-4_331-1> accessed 11 January 2021; Chaim Zins, 'Conceptual approaches for defining data, information, and knowledge' (2007) 58(4) Journal of the American Society for Information Science and Technology, $479<$ https://doi.org/10.1002/asi.20508> accessed 11 January 2021. Given that information is secondary to data which were processed in such a manner as to give them concrete value and make them capable of being used in decision-making, communication processes are going to be described in the context of access to data. Nevertheless, any reasoning related to the way of exchanging data or making that data available retains its relevance for information.

5 Data represent facts, which are registered, processed, and transmitted or made available. On their own, data as such have neither meaning nor purpose. However, its transmission or making them available always occurs for a particular reason, which in turn affects the interpretation of the recipient. Moreover, information is the data contained in the communiqué, which were interpreted by the recipient. Thus, data have objective character, while the character of information is subjective. Mariusz Grabowski, Agnieszka Zając, 'Dane, informacje, wiedza próba definicji' (2009) 798 Zeszyty Naukowe Uniwersytetu Ekonomicznego w Krakowie 111; Gene Bellinger, Durval Castro, Anthony Mills, 'Data, Information, Knowledge and Wisdom ' (2004)<http://www.Systems-thinking.org/dikw/dikw. htm $>$ accessed 11 January 2021; Jennifer Rowley 'The wisdom hierarchy: Representations of the DIKW hierarchy' (2007) Journal of Information Science $<$ https://jo urnals.sagepub.com/doi/10.1177/0165551506070706> accessed 11 January 2021; David Weinberger, 'The problem with the data-information-knowledge-wisdom hierarchy` (2010) Harvard Business Review < https://hbr.org/2010/02/data-is-to-info -as-info-is-not> accessed 11 January 2021. 
As a consequence, many data were being duplicated at many locations. Due to the time-consuming and multistage process of handling physical media within an organisation or between parties to the communication process that were external to that organisation ${ }^{6}$, it was not uncommon for the data to lose their quality of being essential or up-to-date. However, that was dictated by the restrictions resulting from the technical capabilities of that time. When the use of new technologies in the work of an organisation was becoming common, such a traditional approach to the exchange of data was replicated, yet the transmission of data via the means of electronic communication appeared in place of the transfer of physical media. Regrettably, documents were still being generated (for most commonly in that very form the transmission of data was taking place) and actually sent between users inside or outside an organisation. Only the carrier changed, for predominantly that was e-mail instead of mail construed traditionally, as circulation of physical consignments. In that instance, the process of communication was only supported through LegalTech 1.0-type solutions. Data were being transmitted to many locations, where their copies containing versions of files with varying degrees of current relevance were then present. Those were incapable of being used by algorithms. That often led to chaos regarding information, as the participants of the very same process were making decisions based on data that were only ostensibly identical, i.e. working on different versions of the same document (file). That approach changed only recently, even though the technical capabilities themselves were already present for some time. However, the emergence of faster transmission of data, available mobile devices with large data capacities, and a change in the mentality of users were needed. Instead of transmitting data, making the data available became ever more popular. Above all, this is done by uploading the data to a cloud and then allowing authorised entities access thereto. Some lawyers and organisations stopped at this stage. As of now, contemporary organisations still base themselves on a cloud, but store data while using DLT and blockchain. That allows for simultaneous, multi-location data storage, which is implemented in real-time. A distributed ledger provides the possibility of very fast access from the nearest (fastest) node. Security is increased when compared to traditional communication (via e-mail). It

6 "Process" understood here as a collection of reciprocally linked actions, the performance of which leads to the achievement of a specified outcome. Where a process of communication is concerned, the purpose thereof is to create a communiqué by a sender, and then the sending thereof, its receipt by a recipient, and its interpretation in a manner expected by the sender (decoding). 
is important to note that every alteration of data (overwriting) in real-time is available to all those who are authorised, and each entry on every node is original by nature (which prejudges, for legal purposes, many national legal enactments on blockchain).

Where there is transmission of data, there is a transfer thereof from the sender to the receiver and saving of that data on local drives or other permanent data media of the communicating parties. In Economy 4.0, or Digital Economy 3.0, where the circulation of data is very fast, data saved in such a manner are often back data. However, making data available consists in allowing concurrent access to data for entitled or authorised entities (this pertains both to making data available from a single server, groups thereof, or by DLT).

A recipient is unambiguously defined in the event of traditional transfer of data. When making data available, the scope of addressees needs to be specified, and said scope may be unlimited (publicly available data, without the need to identify users) or limited (defined by the provisions of law or by security policy of an organisation). As opposed to the transmission of data, which takes place at a given moment (which results in the data that are up-to-date at the moment of transmission), making data available ensures access to data that are always up-to-date. An entitled or authorised entity has access to data at any time, and that data are aggregated and updated in specified time intervals on a single resource (the single source principle) or in distributed ledgers (DLT). Data in automated systems based on blockchain are updated constantly, which guarantees their up-to-date nature. Such a model not only ensures the up-to-date relevance of data, but also is a guarantor of their credibility. There is a risk of incorrect duplication of databases in the traditional model of transmitting data, which causes a danger of appearance of many different sources of data. The latter may result in a distortion of the decisional process, due to the differences between the contents and the up-to-date nature of the databases. That problem does not occur in the event of making data available or using DLT and blockchain. The extant LegalTech solutions (in particular those that are cloud-based) allow for creating access (granting authority) in accordance with the desired key criterion (taking account of the provisions on personal data protection and relevant security principles). Such a manner of working on data ensures greater efficiency and accelerates the processes in an organisation, which in turn translates to the efficacy of operation and ultimately to the reduction of costs. For that reason, the traditional, archaic model of service is being phased out in favour of making contemporary cloud-, DLT, or blockchain-based data available in real-time. 


\section{Example}

In the traditional manner of communication, a notice of the date of a hearing, served on paper or through the means of electronic communication, requires interaction on part of a lawyer - reading the correspondence, entering it in the calendar, etc. This is carried out by a clerical office in organisations with low digital expertise. In contemporary systems, that process is carried out automatically without participation of a human. A date of a hearing is entered into the system, and by virtue of an application programming interface (API) that data are downloaded and saved in a lawyer's calendar. Entering a hearing date into a calendar, change thereof, or taking it out of the docket altogether occur automatically in accordance with the time interval of data synchronisation; at best, there may be subsequent notice of that fact to the user, through sending of an alert. Contemporary LegalTech systems also allow for verification of calendars and fixing a date acceptable for anyone concerned.

\section{Data Sharing}

\subsection{Introduction}

Making data available should be distinguished from sharing of data, understood as collaborative work on a certain resource by many entities. Like the example of making data available, such a form of cooperation was limited in the past by the capabilities of transfer, having been often effected at the expense of efficiency. In the age of fast Internet and universal use of mobile devices those requirements are no longer relevant. Secure sharing of data by collaborating entities and their clients (both in the public and private sectors) undoubtedly contributes to the improvement of business efficiency. Additionally, data sharing reduces the risk of the loss of data, whereas the model of independent work on data requires the management of multiple workstations to that end. The risk of equipment failure or theft may lead to loss of valuable data, in particular where they are stored on non-secure IT data media. For many years, transferring data and the calculations connected to them to secure, appropriately administrated servers and access to data and applications through remoted desktop protocols was the alternative. The alternative now is the blockchain, which ensures the security of data. Data sharing means that there is a possibility of concurrent work of many users on various databases, including on various sets of data. In such systems, ensuring the versioning of shared documents 
and visualisation of any introduced changes are required, together with unambiguous identification of the author of such changes. Solutions available on the market allow for registration of information and its storage in logs as regards any changes, the moment of effecting a given change, and on the person, who introduced such a change. Collaborative work on data requires implementation of such mechanisms ensuring accountability and identification of changes. Moreover, algorithms managing databases of that type facilitate gradation of access from read-only privileges to highest privileges related to modification and deletion of data. As of now, the development of solutions supporting the flow of data is of strategic importance for an organisation, in particular because of the fact that LegalTech 2.0 solutions are used for work on a large volume of data. They support the processes carried out hitherto by humans, through automation of those processes.

\section{Example}

Pursuant to the traditional approach, documents were sent and duplicated for the purposes of various organisations. Contemporary systems use multiple sources (which increasingly use blockchain in modern organisations). Alteration of data in one location causes automatic access in other systems and affects the possibility of decision. For instance, with properly configured LegalTech solutions, recording a death certificate of person $\mathrm{X}$ in vital records is automatically available for a judge adjudicating a case against such a person (e.g. in criminal proceedings), with the concurrent foreclosure of making a judicial decision as regards the deceased, discontinuation of proceedings, and the entry of relevant information in the system of the Prosecution Office.

\subsection{Automation of Processes Through Use of Aggregated Data}

The amount of data gathered and made available increases systematically. As a consequence, the functionalities of IT systems facilitating selection and compression of excessive amount of data become especially important. However, that data must have certain features in order to be useful, i.e. they must be up-to-date (as of the moment of decision-making, and they must be provided in due time), complete (they must not be fragmentary), reliable (the source of data must be credible), purposeful (in accordance with the rational premiss of gathering thereof, excess data distort and prolong the decisional process), accurate (to the extent possible). Financial cost borne in relation to the process of data gathering must also remain 
adequately related to the benefits thus acquired. Multiplicity of data which are processed and interpreted within a framework of a given organisation affects the amount of information possessed thereby. This facilitates satisfying the need of information and addressing the so-called information gaps resulting from e.g. the need to make a decision.

The above is no different when it comes to public bodies, where the possibility of monitoring the flow of cases, or ensuring the requisite solutions allowing for oversight at every level are also matters of great importance. Moreover, efficacy of proceedings in the age of LegalTech solutions remains closely related to the facilitation of commencement of proceedings via electronic means and to implementation of effective electronic service of process. In turn, management of those processes requires automation at the stage of commencing proceedings, registration of a case, or administrative-clerical service. Advantages of automation of processes occur where the workload in the form of input of data, completed once, pays dividends at the subsequent stages of service. Thus, in a situation where the user would manually input a specified set of data, other systems or other users are going to use that data at subsequent steps in an automated manner. In state-of-the-art systems the input increasingly occurs automatically and is made by devices, e.g. by IoT. The ever-stronger pressure on the integration of IT systems and automation of acquisition of required data is noticeable. Such an automation may support the process of user identification and authorisation, making required data available at the stage of support for the decision-making process, or, finally, transmitting information on the final decision to entitled parties. All of those stages within a correctly planned integration may take place without involvement of the human factor, with the concurrent guarantee of authenticity and integrity of data. It is vital when designing IT systems serving public or private bodies (in the event of access to public databases) to ensure mechanisms of data integration (Application Programming Interface, API) from various databases with a given application, which expands its availability and allows for effective interoperability ${ }^{7}$. However, increasingly more powerful databases come into being as a consequence thereof, and work on them slowly goes beyond the cognitive capabilities of a human. For that reason, ever stronger emphasis is put on the development of LegalTech 3.0 solutions

7 As a result, the way work is organised changes as well. An example of that is making the API to the Information Portal of the Common Courts in Poland available. That caused a bolstering of interest among the bodies offering commercial programs for law offices in integration thereof with their systems. 
that use machine learning (the so-called weak AI) for contextual resource search $^{8}$.

\section{Example}

An instance of simple automation in the area of the judiciary in organisations of mid-range digital expertise is the supplementation of data in documents from other data, e.g. from a claim (mutatis mutandis - from an application to commence non-contentious proceedings, or from a different brief initiating proceedings). Those data are entered into the internal system of a court without involvement (or with little support) of the human factor. Then, the headings for the correspondence to be sent in a given matter (and sometimes even its contents) are generated automatically on that basis. At the last stage, based on the initial data complemented with data gathered during the proceedings, the routine elements of the final decision are generated. Another example, applied in organisations of broader digital expertise, is the one from point 1.2.1, as applied in e.g. Estonia?.

\subsection{Searching Through Data}

Where there is a large volume of data, it is always a challenge to ensure that there are mechanisms in place that allow for efficient searching through those data and for effective work while using them. In most systems, input data are structured in accordance with a specified key. Therefore, creating a solution facilitating a search of those databases poses no challenge and only comes down to ensuring the sorting of records from a given column which contain a given string of data, which then comes down to forming queries while using keywords or sorting commands. However, what proves to be a challenge is the contextual search of databases, i.e. through a precise definition of the analysed problem, and acquisition of re-

8 The expression of that is found in the Proposal for a Regulation of the European Parliament and of The Council on European data governance (Data Governance Act) of 25.11.2020, COM (2020), 737 final, 2020/0340 (COD). This is the first of a number of instruments planned by the European Commission in the European Data Strategy. The purpose of that regulation is to stimulate growth of the economy based on data in Europe, through reduction of transaction costs for the exchange of data, improvement of the availability of data for re-use, and stimulation of the actions of neutral data exchange intermediaries (the so-called data brokers).

$9<$ https://ec.europa.eu/cefdigital/wiki/display/CEFDIGITAL/2019/07/29/Estonian+e -File+system > accessed 12 January 2021, <https://scoop4c.eu/cases/estonian-data-exc hange-layer-information-systems-x-road $>$ accessed 12 January 2021. 
sults corresponding to the query made, by virtue of substantive weight (and not only lexical convergence of keywords). In case of public bodies, a database which falls within the concept of contextual search is e.g. a database of judicial decisions (decisions on merits by public bodies). In the event of publishing judicial decisions (be it on commercial websites or on websites available free-of-charge), solutions based on machine learning are used. The first stage where there is a plane for using systems of that type is the one for the process of erasing personal data from the contents of judicial decisions (anonymisation of court decisions). Anonymisation in the Polish Portal of Judicial Decisions of Common Courts ('Portal Orzeczeń Sadów Powszechnych') takes place automatically, due to advanced algorithms of text analysis based on neural networks. The efficiency of the applied mechanism reaches almost $99 \%$ and constantly increases together with the amount of analysed material, as that system is based on neural networks ${ }^{10}$.

The second moment where there is a need to reach for tools using components of artificial intelligence is the process of searching through judicial decisions. With the amount of data which is published as of now, search based only on text search as regards specific phrases yields too large a volume of results. However, content analysis of statements of reasons allows for an appropriate categorisation with the use of IT solutions, which permit a significant reduction in results. The jurisprudence of the common courts gathered and published in dedicated portals exhibits a similarity which may be identified on the basis of various criteria (features). Contents of decisions contain legal bases and references to case-file reference numbers of other cases which constitute closed collections. Moreover, phrases specific for texts of that type are often used. Identification of such existences facilitates search for decisions similar to one another through highlighting the material common features of the documents. However, in the situation where the jurisprudence of the courts is published by those courts in vast quantities, finding information of interest becomes ever more difficult, and the search methods based on outdated methods of comparison and document proximity analysis increasingly less effective. Searching for information of interest becomes time-consuming and less effective with the increasing volume of data in the databases of court

10 Nevertheless, and in spite of such good results, there is a percentage of information remaining that may be omitted. That necessitated the introduction of the human factor into the entire process of publication, in the form of a person verifying the correctness of automatic anonymisation. 
decisions, which must be automatically processed and then assimilated by the user. Correct categorisation of decisions similar on merits allows for saving the time and for open access to sources of legal knowledge by the professionals and by persons occasionally seeking legal aid. It is currently possible to use solutions that would allow aggregating decisions with similar contents in an advanced manner, to allow users to identify decisions with similar facts of the case, or to allow them to track a line of case-law in the scope of a given legal issue. Those capabilities are granted by using AI tools or machine learning algorithms, which made the analysis of natural texts and applying cognitive abilities thereto. Machine learning allows for discerning significant features of judicial decisions not only in the area of taxonomy, but also of semantics. Solutions of LegalTech 3.0, which offer intelligent full-text search methods, methods of creating search results rankings, or methods of finding similar documents, undoubtedly constitute the future of services addressed to lawyers. Work in that area is underway e.g. ${ }^{11}$ in Poland for the system of the 'Portal of Judicial Decisions $^{12}$, in France ${ }^{13}$, in the UK ${ }^{14}$, and in the United States of America ${ }^{15}$.

A similar challenge is posed by the products achieved with use of automatic speech recognition (ASR). ASR systems also use advanced machine learning methods. The degree of precision is adjusted for a given language situation and yields different results when dictating documents (increasingly more common for use in law offices and by judges) than those obtained therefrom through recognition of spontaneous recordings (e.g. from hearings). In case of the former, the degree of correct recognition (even for the legal language) reaches almost $99 \%$. In case of the latter, the end result depends on the quality of the recording ${ }^{16}$. ASR technology and word-spot-

11 European Ethical Charter on the use of artificial intelligence in judicial systems and their environment, Council of Europe, Commission for the Efficiency of Justice (CEPEJ), <https://rm.coe.int/ethical-charter-en-for-publication-4-december-2018/16808f699c $>$ accessed 12 January 202118.

$12<$ www.orzeczenia.ms.gov.pl> accessed 12 January 2021.

13 Case Law Analytics, JurisData Analytics (LexisNexis) <www.doctrine.fr $>$ accessed 12 January 2021.

14 Luminance. HART (analysis - criminal, risk of reoffending) - Harm Assessment Risk Tool.

15 Watson/Ross (IBM), Lex Machina (LexisNexis).

16 For the purposes of automatic speech recognition, the correctness of recognition is calculated by interpreting the results of the WER (Word Error Rate) metric. The WER comes from the so-called Levenshtein distance, but depends on the compatibility of words, and not single letters in words. It consists in comparing the source text with the recognised text, and then calculating a rate provided by a 
ting ${ }^{17}$ became one of the key issues in the field of developing LegalTech 3.0 solutions due to the increasing amount of data stored in the form of recordings (and in particular due to the ever-broader use of electronic official record, long-distance hearings, and trials over the Internet).

\section{Communication by Using IT Solutions}

\subsection{Communication Within an Organisation}

Rapid development of technology in recent years has become an impulse for evolution of organisations, both in the private sector and in the public sphere, towards development of processes supported by IT solutions or implemented entirely through the use thereof. As a consequence, an organisation increases its operational efficiency through use of contemporary technological solutions, aiming to reach digital maturity of an intelligent organisation, understood as the constant process of adapting that organisation to the changing digital environment ${ }^{18}$. The ecosystem wherein both organisations and clients/recipients of services function is defined as SMAC (Social, Mobile, Analytics, Cloud) and is supplemented by the technology of IoT. Development of communications technology remains closely linked to contemporary solutions reinforcing the process of management and the service of processes. Functioning of an organisation in the age of digital transformation requires adjustment of methods

quotient of a sum of substituted, inserted and deleted words and the number of words in the entirety of the text. The ASR system functioning at the Polish courts has a very high level of WER (below $9.5 \%$ for the Polish language). The highest level of WER was achieved for the English language, and it currently amounts to $4.9 \%$ (Google). Emil Protalinski, 'Google's speech recognition technology now has a $4.9 \%$ word error rate ' $<$ https://venturebeat.com/2017/05/17/googles-speech-r ecognition-technology-now-has-a-4-9-word-error-rate/> accessed 11 January 2021.

17 Audio mining or search for information in sound recordings.

18 James Corr 'An introduction to the digital maturity model' (2020) $<\mathrm{https} / / \mathrm{w}$ ww.seerinteractive.com/blog/introduction-to-digital-maturity/> accessed 11 January 2021; Tristan Thordsen, Matthias Murawski, Markus Bick 'How to Measure Digitalization? A Critical Evaluation of Digital Maturity Models ' in Marié Hattingh, Machdel Matthee, Hanlie Smuts, Ilias Pappas, Yogesh K. Dwivedi , Matti Mäntymäki (eds) Responsible Design, Implementation and Use of Information and Communication Technology (Springer-Cham 2020) <https://doi.org/10.1007/ 978-3-030-44999-5_30P> accessed 11 January 2021; Piotr Adamczewski, 'Ku dojrzałości cyfrowej organizacji inteligentnych' (2018) 161 Studia i Prace. Kolegium Zarządzania i Finansów, 67. 
of management and communication to the contemporary standards based on using technology of the so-called Third Platform of ICT (SMAC). An intelligent organisation understood as an economic system utilising advanced ICT infrastructure in its internal organisation and communication (including external communication) constitutes, as of now, the essence for the functioning of information society in business fields ${ }^{19}$. Therefore, ensuring that an organisation is appropriately equipped with system and communications infrastructure, and at times hardware infrastructure, becomes necessary for service of processes inside the unit.

It is now standard to use mobile devices such as smartphones and telephones (Mobile) for communication withing the framework of a given organisation. Analytical solutions become increasingly important (Analytics), as they are capable of providing specific preferences, trends or dependencies on the basis of aggregated data and with the use of advanced algorithms. As a result, the decision-making process is supported at various levels of an organisation. Advantages of that type of analysis are used increasingly more often in law offices and public bodies. And finally, there is the ultimate mainstay of SMAC, i.e. the technology of the computing cloud (Cloud), with DLT and blockchain included therein.

However, using full potential of SMAC requires profound change within an organisation and, above all, abandonment of traditional "analog" solutions in favour of digitalisation. It is much easier to work, make available, process, and analyse sources that were originally created and fixed electronically. This is followed by the need of reorganising personnel towards employees who possess appropriate expertise in that field. Changes in the private sector must also be correlated with changes in the public sphere. A state understood as public administration and the judiciary should also increase the availability of services offered electronically, gather resources of digital data, and create a friendly legal ecosystem. After all, effective use of contemporary technologies in an organisation, automation of repetitive processes, and innovation are one of the components of the so-called process maturity of an organisation ${ }^{20}$.

19 Stewart Clegg, 'Globalizing the Intelligent Organization: Learning Organizations, Smart Workers, (Not So) Clever Countries and the Sociological Imagination, Management Learning ' (1999) Sage journals $<$ https://journals.sagepub.com/doi/a bs/10.1177/1350507699303001> accessed 11 January 2021;

Piotr Adamczewski, 'Organizacje inteligentne w zintegrowanym rozwoju gospodarki ' (2016) 2 Zeszyty Naukowe Uniwersytet Rzeszowski, 420.

20 Vladimir Modrák, Zuzana Šoltysová, 'Development of an Organizational Maturity Model in Terms of Mass Customization' in Dominik T. Matt, Vladimir 
Examples of solutions used outside of an organisation are found in: messengers (e.g. MS Teams), special solutions for collaborative work (e.g. Workplace, Trello), platforms allowing for videoconferencing and online meetings (e.g. MS Teams, Zoom, Jitsi Meet), e-mail based on customised mailbox, integrated with a calendar and available on many devices (e.g. Exchange), corporate social media (e.g. Yammer), workplace collaboration software (e.g. Basecamp or Slack), intranet, newsletters, etc. The solutions thus described are often integrated, which makes the flow of information within an organisation more efficient and consistent.

\subsection{Communication with Parties from Outside an Organisation}

At present, where communication with external partners is concerned - analogously to communication within an organisation - the parties base themselves on SMAC technologies. However, professional messengers (such as MS Teams, Zoom, Google Meet, Jitsi Meet, etc.) that become a platform for swift exchange of information and knowledge sharing, increasingly become the mainstay for such communication. It is not only the private sector that functions within this medium. Ever more frequently, public bodes consider that form of communication - apart from the dominant one, via domain-specific ICT systems - to be permissible as well, which allows an organisation to apply homogenous standards in communication with partners from both sectors. The approach to mobile devices also changes, and in communication with partners from outside the organisation those are used not only as tools for direct communication (in the form of telephone conversation, or of a SMS message), but also - or, above all - as tools for using videoconferencing platforms or ICT systems. Universal usage of smartphones and tablets necessitates that applications and webpages of any kind must also be available in the so-called mobile version, and it must be added that those devices are permanently connected to the Internet. A cloud also finds its use in communication with external parties, by granting specific privileges (access) to defined resources for business partners or service recipients. It also becomes standard to work on a joint project by using specialised solutions, such as JIRA, IC

Modrák and Helmut Zsifkovits (eds) Industry 4.0 for SMEs (Palgrave Macmillan 2020) $215<$ https://doi.org/10.1007/978-3-030-25425-4_8> accessed 12 January 2021, Magdalena Raczyńska ‘Modele dojrzałości procesowej organizacji (2017) XLIV 2 Acta Universitatis Nicolai Copernici. Zarządzanie, 61. 
Project, GanttPRO, Workzone, etc. The solutions described here systematically supersede the methods of communication used hitherto, which in most cases were based on sending an electronic message via e-mail, or on direct communication.

As of now, using uniform methods of communication within an organisation and with partners outside an organisation is noticeable. It is due to the synergy between the four mainstays of the Third Platform of ICT mentioned above that ecosystems that were hitherto closed and often restricted to one organisation and its partners have been opened to third parties, including public bodies. New channels of communication facilitate efficient transfer of information to a broad range of recipients. In turn, mobile technologies guarantee constant access to that information by virtue of a permanent connection to the Internet. Furthermore, data analysis ensures optimisation of processes, while cloud technology facilitates scalability and reduction of costs while working on data. Work within the boundaries of one working environment ensures timesaving and improves the flow of information. However, that requires high standards in the scope of cybersecurity, for hitherto isolated systems or databases are opened for persons from outside an organisation, and thus for persons constituting a potential hazard.

\section{Electronic Services in LegalTech}

\subsection{Introduction}

One of the most important challenges posed for public administration and the judiciary is to ensure efficient communication with other offices, citizens, and entrepreneurs ${ }^{21}$, based on high standards of security and on verification of identity. The most important task in that area is the ensuring of the provision of public services via electronic means, which ultimately is to accelerate and improve deciding cases before public bodies. The concept of an electronic service (e-service) should be construed as a service which may be provided without physical presence of the parties

21 The following communication channels are distinguished: Government-to-Government (G2G) - public authorities to other public authorities, Government-to-Citizen (G2C) - public authorities to citizens, Citizen-to-Government (C2G) - citizens to public authorities, Government-to-Business (G2B) - public authorities to entrepreneurs, Business-to-Government (B2G) - entrepreneurs to public authorities. 
at one given venue (remotely via the Internet) by using information technology (either partially or completely automatically). Such services should be set up in a manner targeted to a citizen, i.e. in a clear, transparent, productive, and effective manner, in order to avoid exclusion of any groups, in particular in the context of the so-called "functional illiteracy", understood as "IT exclusion". Traditionally, there are four stages of maturity for electronic services provided by public bodies, i.e. information, interaction, transactional services, and integrative services ${ }^{22}$. Recently, personalisation was discerned as the fifth stage.

\subsection{Information and Interaction Services}

At the most basic, i.e. at the informative level, the institutions publish information at their websites, while recipients (citizens, clients, users) may only familiarise themselves with such information by browsing webpages through a personal computer, mobile devices, or the so-called information kiosks. At present, the first stage of service maturity is already a standard. Every public body, be it among European Union bodies or within national structures, ensures access to an appropriate collection of information as of now.

The second stage of maturity presupposes one-way interaction. Users transfer information to an institution via electronic means, yet not in all cases the institution would answer them in the same way (communication

22 Janina Banasikowska, Anna Sołtysik-Piorunkiewicz, 'Czynniki kształtujące poziom akceptacji i poziom dojrzałości systemów e-administracji na tle rozwoju społeczeństwa informacyjnego ` (2016) 308 Studia Ekonomiczne. Zeszyty Naukowe Uniwersytetu Ekonomicznego w Katowicach, 9 and literature cited thereunder. Alternatively, there is another categorisation of services posited in the academic literature, in that there are: Level - 1: Information, Level 2 - unilateral interaction, Level 3 - bilateral interaction, Level 4 - transactional, Level 5 personalisation; alternatively, there is a categorisation of: cataloguing (in that an organisation has a webpage), transaction (there is a possibility of providing services for citizens electronically, but only coming down to the option of making a service of downloading interactive forms from a website and transmitting them to that authority available), vertical integration (databases of various organisations are integrated, there is a possibility of making a decision on a case electronically), horizontal integration (linking various data systems that comprise separate groups of services provided for citizens, by which a citizen becomes able to have his or her various cases "heard" at a single place). Karen Layne, Jungwoo Lee, 'Developing Fully Functional e-Government: A Four Stage Model' (2001) 18 Government Information Quarterly 122. 
may be unilateral, when only the input of information occurs electronically, or bilateral, where an authority responds that way as well).

\subsection{Transactional and Integrative Services. Personalisation as the Fifth Stage of Maturity for e-Services}

In the transactional model, the recipient communicates with a public office via electronic means and in that way receives a reply (communication is bilateral, often using dedicated applications, e.g. through completing a form on-line and sending it with attachments to a public authority via electronic means).

At the fourth stage, i.e. the integrative stage, users access dedicated portals on which they use information from various parties. This is made possible due to integration of data from such various sources, and thus work is carried out with the use of shared data. The entire process commences wholly via electronic means. From the acquisition of information, commencement of proceedings, payment of an appropriate fee, to the making of either a procedural or substantive final decision on the case at the end ${ }^{23}$.

Lastly, personalisation consists in offering services to users where such services are customised for individual needs and circumstances of those users. Due to the implementation of appropriate algorithms of data processing, services are automated and provided proactively (that is, the institution itself reaches to the recipient with the proposal of providing a service).

\section{New Approach to Directness ${ }^{24}$}

\subsection{Introduction}

IT solutions alter the way in which lawyers operate. Major acceleration of changes has occurred due to COVID-19 and thus the inability to operate as usual, i.e. through direct physical meetings, either with clients or

23 ibid.

24 Ewa Rott-Pietrzyk, Dariusz Szostek, 'A New Approach to the Legal Understanding of "Directness" and "Participation" in the Aftermath of COVID-19' in: Ewoud Hondius, Marta Santos Silva, Andrea Nicolussi, Pablo Salvador Coderch, Christiane Wendehorst, Fryderyk Zoll (eds) Coronavirus and the Law in Europe 
with a court ${ }^{25}$. We stood witness when the work methodology of lawyers (through universal use of videoconferencing), institutions (including the courts), and the interpretation of the concept of "being in the presence" have changed in mere weeks. Before the pandemic, that last concept was interpreted restrictively, equating it with physical presence at the same place and at the same time ${ }^{26}$. By adopting a purposive interpretation without actually amending the law, holding online meetings and sessions (including those of the European Parliament or those of national parliaments, administrative authorities, or companies), where members connect thereto via IT solutions and participate in proceedings in real-time. That change shall last, including after COVID-19. Online hearings became obvious. In just several days, online trials were greenlit as well, in countries where this was impossible until that time (to that extent, an amendment of the law was needed at times, and sometimes the existence of online trials had to be "discovered" in existing provisions), deeming that online solutions fulfil the requirements of directness. Lithuania, Italy, or Norway may be indicated as examples in that regard ${ }^{27}$. In other countries the legal bases (which were admittedly extant) were expanded to include a possibility of holding trials on-line for lower instance courts and the opportunity of connection from a different venue that that of the court. Such acts were taken inter alia in Poland, Brazil, and Canada ${ }^{28}$. In countries with substantial digital expertise (e.g. in Austria) the conduct of notaries changed, and permission to draft notarial deeds online was given. More importantly,

$<$ https:/www.intersentiaonline.com/publication/coronavirus-and-the-law-in-euro pe/658?version=v-2f6f01ec-324e-637b-c7ca-a6bc0e384e16> accessed 15 December 2020.

25 Tiffanie Wen, 'How coronavirus has transformed the way we communicate' (BBC, 9 April 2020) <https:/www.bbc.com/worklife/article/20200408-coronavirus -how-lockdown-helps-those-who-fear-the-phone> accessed 15 December 2020.

26 However, there emerged a concept of "tele-presence" in the doctrine, as an alternative to the traditionally understood physical presence. Nonetheless, those analyses more often pertained to the ODR rather than to classic judicial procedures. The COVID-19 pandemic caused this view to shift and intensified a wider use of videoconferencing platforms for the purposes of organising a court hearing. Richard Susskind, Online Courts and the Future of Justice (Oxford University Press 2019) 255.

27 Ewoud Hondius, Marta Santos Silva, Andrea Nicolussi, Pablo Salvador Coderch, Christiane Wendehorst and Fryderyk Zoll (eds) Coronavirus and the Law in Europe <https:/www.intersentiaonline.com/bundle/coronavirus-and-the-law-in-europe> accessed 12 August 2021.

28 ibid. 
ISO 29115 technical norms ${ }^{29}$ on identity assurance at the LoA2 or LoA3 levels, and thus at the average or high levels of assurance, respectively, permit identity verification carried out fully online. At the global level, the SP 800-63 guideline introduces 4 individual assurance levels; at IAL2 and IAL3, verification of identity online is permissible, on condition that where the latter level is concerned there would be an online connection of a trained employee with the person being verified, and verification of identity would take place via that transmission and verification of an ID card with a photo. As of this moment, there are actions being considered whose purpose would be to verify identity with an entry in blockchain, taken together with additional attributes which could be freely added by the verified person to his or her data (e.g. an attribute of the entry in the Bar, on the roll of notaries, etc).

\subsection{Electronic Hearings According to the Example of European States}

Remote hearings (also known as electronic hearings, online hearings, hearings over the Internet, or "devenued" hearings ${ }^{30}$ ) are a specific example of electronic services offered by the judiciary. Receipt of information is an active and complex process, in which the mind cooperates with the senses to create an image of the reality surrounding us. Among them, sight is the most developed sense and has greatest importance in the process of perception. Moreover, studying the reaction of the person heard allows a judge to swiftly respond by appropriately adjusting and rephrasing questions. The advantages of a remote hearing caused it to be universally used in the states of the European Union for many years already, both in civil and criminal proceedings ${ }^{31}$. Audio-video streaming, in itself, is being developed,

29 <https://www.iso.org/standard/45138.html> accessed 10 December 2020.

30 As they are referred to in Poland.

31 A tool named "Telehoren" has been used in the Netherlands since 1999 (Aarnout Schmidt, 'Technologie komunikacyjno-informatyczne w sądownictwie w Holandii - aktualna sytuacja' (2006) 16 Prawo mediów elektronicznych). In Austria, Germany, Finland, Estonia and Poland, a remote deposition was consistently being implemented for successive courts during the first years of the $21^{\text {st }}$ century (Jacek Gołaczyński (eds) Informatyzacja postępowania sadowego w prawie polskim $i$ wybranych państw (C. H. Beck 2009) 36. The option to use videoconferencing to render legal assistance between courts of various states was provided for under the Convention established by the Council in accordance with Article 34 of the Treaty on European Union, on Mutual Assistance in Criminal Matters between the Member States of the European Union OJ C 197/12 and under Council Regu- 
and associated services such as autodescription or VMI (video-mediated interpreting) are being activated ${ }^{32}$.

The next stage of development for audio-visual communication between a court and the parties to the proceedings is the so-called electronic (on-line) hearing. It is based on the assumption that not only witnesses or expert witnesses but parties to the proceedings in general may be present at other venues that that of the court hearing the case. In that event, the parties may take part in a hearing while being physically present at a different courthouse and take action in proceedings from there. The course of proceedings is transmitted in real-time to the place of stay of the parties and to the court holding proceedings ${ }^{33}$. The SARS-CoV2 pandemic has made the use of audio-visual techniques universal, as an alternative to personal appearance in court. It has also generated an impulse to abandon the traditional transmission between stations located in courts, penitentiaries, or other organisational units of the judiciary. Moreover, solutions allowing participation in a court hearing from any place where a party is present have appeared ${ }^{34}$. At an online hearing, a party to the proceedings may effectively take any procedural acts, with legal effects prescribed in the legal provisions ${ }^{35}$. One may discern hearings where some parties connect remotely (partially remote hearing) and hearings wherein everyone (including the composition of a given court) participates remotely (fully remote hearing).

An addition to the active communication between a party and a court is found in passive communication, consisting in streaming the hearing

lation (EC) No 1206/2001 of 28 May 2001 on cooperation between the courts of the Member States in the taking of evidence in civil or commercial matters OJ L $174 / 27$.

32 Sabine Braun, 'Remote Interpreting' in Holly Mikkelson and Renėe. Jourdenais (eds) Routledge Handbook of Interpreting (Routledge 2015)352. <http://wp.videocon ference-interpreting.net> accessed 12 January 2021.

33 Anna Zalesińska, 'Electronic Court Report in Proceedings Before Common Courts in Poland' in: Jacek Gołaczyński, Wolfgang Kilian and Tomasz Scheffler (eds) Legal Innovation in Polish Law (C. H. Beck 2019) 119-131.

34 To illustrate, such a solution was provided in Poland by the Act of 14 May 2020 on the amendment of certain statutes in the scope of protective acts related to the spread of the SARS-CoV-2 virus (Journal of Laws of 2020, item 875).

35 The level of maturity for a e-service of holding a hearing online was defined at $4^{\text {th }}$ level. This means fully settling a matter by making an application to hold a hearing online, then processing that application, planning a videoconference and confirmation of a date, allocation of resources, and finally holding a hearing. 
on-line ${ }^{36}$. That functionality comprises allowing the authorised persons to stream the course of public hearings through the videoconferencing infrastructure. The examples of programs used to organise videoconferences at courts are: Microsoft Teams (Italy), Skype for business (Hungary, the UK, the Czech Republic), Zoom (Great Britain's Northern Ireland), BT MeetMe (Great Britain's Northern Ireland), Sightlink (Great Britain's Northern Ireland), Jitsi Meet and Avaya Scopia (Poland), the respective countries' own systems (Spain). The SARS-CoV-2 pandemic made the implementation of systems handling videoconferencing in common courts of the Member States of the EU more intense. Admittedly, a remote hearing was possible in some states even before 2020. For instance, there were no material changes to the operation of the judiciary in Croatia, as communication via electronic means and remote hearings in civil and commercial matters were also possible even before the pandemic. That state of affairs is similar in Estonia, where it was also made possible in any given type of cases, regardless of the role or function performed in proceedings. There also was a possibility of organising remote proceedings in Finland, including through videoconferencing, both in civil and criminal cases. Furthermore, there were provisions in force in Germany before the pandemic that allowed the parties, their representatives and advisers to provide testimony during a pending hearing from various venues, i.e. not necessarily from the courtroom. In some Member States of the EU, the pandemic accelerated the implementations or became an accelerant for new, innovative projects. Ireland is a good example of that, for it took the pandemic to start work related to ensuring appropriate legislation and infrastructure for the purposes of videoconferencing there. Pilot stages did not commence until April 2020. In two regions of Spain which belong to the most advanced as regards the implementation of videoconferencing systems, that is in Valencia and Catalonia, there is a possibility since April 2020 for an arrested person or a person held in custody to make a remote deposition and for an expert to give testimony (respectively, by using the CISCO WEBEX system in Catalonia), or solely for an arrested person (in Valencia). While regulations allowing for remote hearings in Lithuania were introduced for civil cases, they were used only sporadically until the pandemic. There also was an initiative in April 2020 to ensure broad use of videoconferencing also in criminal proceedings. As far as the analogous situation in Poland was concerned, remote hearings were used

36 Streaming understood here as a transfer of data from one device to another, which allows for playback of data in real-time. 
sparingly (yet much more often in criminal matters). Remote trials, despite the provisions that allowed them already in 2015 , were not garnering a great amount of attention. It was from May 2020 that the change came, after amendment of the provisions on remote participation in a civil trial from any place, without the need to stay in a courthouse. Abandonment of the requirement to be present at a courthouse has contributed to the promotion of the tool at issue and to renewed interest in such a form of participation from the parties to proceedings. What is more, there were two new types of commencing proceedings adopted in Italy during the period of the pandemic, i.e. the "mobile" one (document-based) and remote proceedings in the form of videoconferencing through a dedicated application. There was a project called "Skype Defence", launched in January 2020 in the Czech Republic, allowing remote communication for defence counsel with their clients who were present in penitentiaries. It was not until a temporary regulation on administration of justice, which came into force on 28 March 2020, that commencement of hearings via videoconferencing was allowed in Norway. In a similar vein, Hungary allowed an option of broad use of videoconferencing in civil and criminal matters at the beginning of April 2020. In Portugal and Sweden, court systems were adjusted after April 2020 to carry out videoconferencing where it would be compatible with the right to fair trial. In addition, there are states which use videoconferencing in a very limited manner, e.g. in Austria, where videoconferencing came into use only when the pandemic started, and only in criminal proceedings. Courts in Denmark restricted themselves to the option of holding a hearing mainly via electronic means (to a very limited extent, with the use of tools allowing audio-visual transmission $)^{37}$.

\section{Electronic Service of Process}

\subsection{Poland}

Due to organisational considerations and the costs associated thereto, computerisation of the judiciary in Poland progresses in stages. It was at the

37 Drafted on the basis of the document by the Foreign Affairs Committee of the National Assembly of Attorneys at Law. Krajowa Izba Radców Prawnych, 'Sądy w trybie online - zdalna praca sądów w wybranych państwach europejskich w czasach pandemii SARS-COV-19' (2020)<https://kirp.pl/wp-content/uploads/202 0/05/opracowanie-komisji-zagranicznej-krrp.-sady-w-trybie-online.pdf $>$ accessed 13 January 2020. 
end of the past century when the first acts in the field of computerisation of court registers were taken. As of now, the management of the register of sentenced persons (State Criminal Register) ${ }^{38}$, the land register ${ }^{39}$, the register of liens, and the register of business entities (National Court Register) ${ }^{40}$ is carried out remotely. From 2009, when Electronic Admonitory Proceedings (Elektroniczne Postępowanie Upominawcze, "EPU") 41 appeared in the Polish Code of Civil Procedure, the process of computerising the judiciary undoubtedly gained greater momentum. The electronic record of proceedings began to exist in 2010 beside the traditional written record of proceedings $\mathrm{s}^{42}$. Following the example of civil proceedings, similar changes appeared within the proceedings in matters of contraventions and in criminal proceedings. The next stage was to implement oral statements of rea-

38 The IT system of the State Criminal Register cooperates with the Central Register of Vehicles and Drivers (Centralna Ewidencja Pojazdów i Kierowców) and with the IT system of the Central Board of the Prison Service at the Ministry of Justice. Since 2008, the State Criminal Register has cooperated with other criminal registers from some EU Member States through the sTESTA network.

39 It is possible to consult the entirety of the land register ("księga wieczysta") through that system, obtain a certified copy, and verify authenticity of a print-out. There is an additional functionality of access to electronic notices on entry and to information on the state of a case to make an entry to the land register through the trusted ePUAP user profile (which is one of the national methods of identification in Poland, equivalent to a qualified electronic signature).

40 The currently available electronic services are: an Internet-based search engine for entities entered into the National Court Register; independent downloading of print-outs from that Register, which enjoy the legal status of a document issued by a court; making applications on-line to enter an entity into the National Court Register; making applications to enter a Polish private company limited by shares (a "sp. z o.o.”), a Polish registered partnership (a "sp.j.”), and a limited partnership (a "sp.k.") to the Register (the so-called S-24 company module, which allows registration of those types of companies and partnerships through a readymade template over 24 hours); ordering and receiving documents online from the corporate catalogue of documents.

41 Introduced by the Act of 9 January 2009 on the amendment of the Act - Code of Civil Procedure (Journal of Laws of 2009, item 156.). Consists in a simplified procedure of litigating money claims by completing an online form by the claimant (including by the so-called mass claimant), and in paying a judicial fee over the Internet. The claimant receives an order for payment to his or her account in the IT system, while the defendant is served therewith by post. An order for payment contains an identification code which allows for verification that the payment order exists and what are its contents in the IT system. There is an option of electronic (i.e. remote) commencement of civil enforcement proceedings.

42 Until 2010, there only was an option in judicial proceedings to take evidence remotely by way of videoconferencing. 
sons for decisions into the proceedings, and then online hearings in 2015, as other European states did. According to Article $151 \$ 2$ of the Polish Code of Civil Procedure ${ }^{43}$, it is possible to order the commencement of a public hearing via technical means that would allow to carry it out remotely. In that event, parties to the proceedings may take part in the hearing while being physically present at some other venue and take procedural acts from there. The course of procedural acts is transmitted in real-time to the place of stay of the parties and to the court holding proceedings. The venue at which the parties may take part in a public hearing should be located at the courthouse of a different court. A major improvement for the purposes of applying for that very manner of holding a public hearing is found in the option of filing an application therefor via the Information Portal. Feedback communication with a court takes place electronically, as well. It is worth noting that the application for an on-line hearing made via electronic means is a first-of-a-kind service in Poland which is provided completely through the Internet, and thus the first service of the so-called Electronic Internal Mail Department (Elektroniczne Biuro Podawcze $)^{44}$. Everything in that regard depends on the technical capabilities present at a given court, in a given category of cases, or in the scope of a given procedural act. Such a capability was ensured for the application for an online hearing. However, such an application must be signed in accordance with Article $126 \$ 5$ of the Polish Code of Civil Procedure, i.e. by a qualified electronic signature, by a trusted signature, or by a personal signature. The existing option to hold a hearing online with the participation of parties present in different courthouses was expanded in 2020. The state of the law

43 Act of 17 November 1964 - Code of Civil Procedure (consolidated text: Journal of Laws of 2020, item 1575, as amended).

44 The concept of the Electronic Internal Mail Department should be understood here as a complete solution that enables both the filing of briefs in an electronic manner and the electronic service. The provision of Article $125 \$ 2^{1 \mathrm{a}}$ of the Polish Code of Civil Procedure uses the phrase "selecting the option to file briefs (...) and subsequent filing of briefs" is permissible where it is possible due to technical reasons attributable to a given court. This should be understood in such a way that if the technical reasons permitted the handling of one type or category of cases, then only to that extent electronic communication at a given court would take place. Therefore, based on Article $125 \rrbracket 2^{1 a}$ of the Code, it is possible to file a specific brief through a ICT system that serves judicial procedures, on assumption that the proceedings then continue "on paper". Marcin Uliasz in Jacek Gołaczyński and Dariusz Szostek (eds) Kodeks postępowania cywilnego. Komentarz do ustawy z 4.7.2019 r. o zmianie ustawy - Kodeks postępowania cywilnego oraz niektórych innych ustaw (C. H. Beck 2019) 72. 
was subject to change due to passing a governmental bill to amend certain statutes in the scope of protective acts related to the spread of the SARSCoV-2 virus ${ }^{45}$, where the legislator decided to allow a broad participation in a hearing through a videoconference. According to Article $15 \mathrm{zzs}^{1}$, the participants in an online hearing need not be present at court and may participate in a hearing remotely, by using a personal computer or a mobile device. Connection takes place by using two applications, i.e. Avaya Scopia or Jitsi Meet (the court decides which one is to be used). The entirety of the hearing is held remotely, including the delivery of a judgment and the presentation of the oral grounds therefor, or the provision of an oral statement of reasons ${ }^{46}$.

The Information Portal was implemented into the court system together with the e-record of proceedings. It is a system allowing an authorised user to gain access to information on a given case, to court documents, to recordings of the electronic record ${ }^{47}$, and to the Portal of Judicial Decisions mentioned above. Finally, the date of 10 July 2015 is of note here, as on that day the provisions allowing comprehensive service of fully electronic, bilateral communication with a court in civil matters were passed. Thus, the legislator allowed wide use of electronic and documentary forms in the context of recording court documents in the course of civil proceedings. However, the IT system was not created, and the administration of justice was mainly based on "paper-based" service of process (with

45 Act of 2 March 2020 on special solutions related to the prevention, counteraction and combating COVID-19, other infectious diseases and crisis situations caused thereby (Journal of Laws of 2020, item 1842, as amended).

46 Should a hearing be recorded by a device recording sound, or images and sound, the Polish legislator introduced the possibility for the statement of reasons to be delivered after the delivery of the operative part of the judgment, and then recorded by that device, in civil proceedings and in proceedings in the matters of contraventions. Oral statement of reasons becomes a part of the electronic record of proceedings. Anna Zalesińska, 'Electronic Court' in Jacek Gołaczyński, Wolfgang Kilian and Tomasz Scheffler (eds) Legal Innovation in Polish Law (C. H. Beck 2019), 119.

47 E-services for citizens are provided through the Information Portal, i.e.: an application for automatic transcription solely by using automatic speech recognition (ASR), application to make an audio-video recording available, application to reserve a station to consult the electronic official record at the file-reading room, an application for an e-hearing (the first application within the framework of the so-called Electronic Internal Mail Department). There is going to be an application for the streaming of a hearing, to be made available in 2021. 
minor exceptions described above) until $2020^{48}$. This is not to say that electronic service of process was not carried out. Public administration and the judiciary implemented that service in a limited ${ }^{49}$ manner ${ }^{50}$, in differing ways and by using different IT systems. Even within the bounds of the widely understood public administration (tax offices, the Social Insurance Institution, etc) there were divergences, in particular during the first years of implementing electronic communication ${ }^{51}$. That situation changed greatly on 18 November 2020, when the Act on Electronic Service was passed. However, implementation of electronic service and the creation of a system handling them is planned to take years, for this is a major organisational undertaking. Completion thereof is planned for as late as 2029. Due to the circumstances related to the pandemic, the Polish legislator has decided in 2021 to temporarily allow the possibility of carrying out effective electronic delivery service via Case Information System (Portal Informacyjny) ${ }^{52}$. Where cross-border communication is

48 Although the traditional postal receipt was superseded by an electronic receipt, the so-called Electronic Confirmation of Receipt.

49 Limited because only certain types and kinds of cases were capable of being managed remotely.

50 The duty to carry out electronic service on demand appeared in administrative procedure already in 2005. In civil proceedings, electronic service was performed only in select types and kinds of cases. By way of an example, one may point to the Electronic Admonitory Proceedings mentioned above.

51 The development of e-services has advanced greatly in recent years in Poland, and public bodies ensure the possibility of settling select cases over the Internet via those e-services for potential stakeholders.

52 Article $15 \mathrm{zzs}^{9}$ of the Act of 2 March 2020 on special solutions related to the prevention, counteraction and combating COVID-19, other infectious diseases and crisis situations caused thereby (Journal of Laws of 2020, item 1842, as amended), which came into force on 3 July 2021. 
concerned, the eCODEX ${ }^{53}$ and eCODEX Plus project ${ }^{54}$ wherein Poland participated becomes of special importance. The purpose of that project was to create legal and factual capabilities of electronic receipt of briefs within the framework of two cross-border judicial procedures - the European Order for Payment ${ }^{55}$ and the European Small Claims Procedure ${ }^{56}$, by connecting the courts of Member States which participated in the project to the e-Justice portal (e-justice.europa.eu) and by introducing appropriate legislative amendments to the provisions of civil procedure in force ${ }^{57}$. The

53 The e-CODEX project (carried out from 2010 to 2016) greatly influenced the development of computerisation of judicial procedures in the European Union. The concept of the e-Justice portal (e-justice.europa.eu) was drawn up within the framework of that project, to serve as a pan-European contact point in matters of the administration of justice. Furthermore, the project produced steering guidelines for subsequent work on filing and serving briefs and court letters via electronic means. The effects of that project were met with positive assessment from the European Commission and adapted in the work of the European legislator. Katarzyna Klimas and Damian Klimas, 'Electronic Communication in European Cross-birder Proceedings - Polish Perspective' in Jacek Gołaczyński, Wolfgang Kilian and Tomasz Scheffler (eds) Legal Innovation in Polish Law (C. H. Beck 2019)197; Communication from the Commission to the European Parliament, the Council, the European Economic and Social Committee and the Committee of the Regions. Digitalisation of justice in the European Union A toolbox of opportunities, Brussels, 2.12.2020 COM(2020) $710<$ https://ec.europa.eu/info/sites /info/files/communication_digitalisation_en.pdf $>$ accessed 12 January 2021.

54 National ICT systems were successfully connected to a central portal within the framework of the eCODEX Plus project (carried out from 2017 to 2019). Pilot actions pertained to two procedures, i.e. procedure for the European Order for Payment and the European Small Claims Procedure. The pilot procedure took place at the District Court for Wrocław - Fabryczna in Wrocław and at the Regional Court in Wrocław.

55 Regulation (EC) No 1896/2006 of the European Parliament and of the Council of 12 December 2006 creating a European order for payment procedure, OJ L 399/1.

56 Regulation (EC) No 861/2007 of the European Parliament and of the Council of 11 July 2007 establishing a European Small Claims Procedure, OJ L 199/1.

57 The Polish legislator did not foresee the option of using contemporary technological solutions within the scope of provisions directly applicable to European cross-border procedures. However, legislative solutions foreseen by the European legislator allow for computerisation both the European Order for Payment procedure and the European Small Claims procedure. Using electronic communication between the courts of a given Member State hearing the case in one of the European cross-border procedures is made possible in particular by Article 26 of Regulation no. 1896/2006, which states that all procedural issues not specifically dealt with in that Regulation shall be governed by national law, and by Article 19 of Regulation no. 861/2007 which states in turn that subject to the provisions of that Regulation, the European Small Claims Procedure shall be governed by 
project was a success, and the platform itself is going to be used to handle the next process, i.e. the transmission of applications and notices pursuant to Council Regulation (EC) No 1206/2001 of 28 May 2001 on cooperation between the courts of the Member States in the taking of evidence in civil or commercial matters ${ }^{58}$.

Within the framework of the so-called back office, there are various IT systems supporting the work of officials at courts, including e.g. electronic clerical system for the courts, a HR/financial system based on the technology of SAP, or the electronic internal mail system. Using e-mail is the standard (the comprehensive implementation of Microsoft Outlook and a central AD domain within the Polish courts was completed in 2021). A videoconferencing system was a popular tool for internal meetings, even before the pandemic. However, solutions present within the Polish judiciary have an insular nature. There are many ICT systems, and not all of them are integrated. Duplicated data are stored on some of them. As it may be noticed, those systems apply to some types of cases, or only to some types of proceedings, or even to specific processes. A comprehensively implemented, homogenous ICT system serving the judiciary is absent in Poland. The potential of blockchain and AI is not realised in the Polish legal system, as of now. To some extent, certain mechanisms support the speech recognition process while transcribing the electronic records and handle the first stage of anonymising statements of reasons. However, automation of decision-making (including the cases of issuing an order for payment) is used only in the Electronic Admonitory Proceedings (and to a limited extent, for that matter) - that is, the draft of an order for

the procedural law of the Member State in which the procedure is conducted. Thus, those provisions grant relative autonomy in the scope of computerisation of those procedures at the national level. Moreover, there are provisions under both Regulations that refer to using electronic communication in European cross-border procedures, while at the same time leaving the decision on the issue of using them to the respective Member States of the European Union.

58 OJ L 174/27. Requests and communications provided for under that Regulation are to be transmitted through a decentralised IT system comprising national IT systems connected by communications infrastructure enabling secure and reliable cross-border exchange of information between national IT systems. A prototype created within the framework of the eCODEX project is to be that system. Cf. Proposal for a regulation of the European Parliament and of the council on a computerised system for communication in cross-border civil and criminal proceedings (e-CODEX system), and amending Regulation (EU) 2018/1726 <https://e c.europa.eu/info/sites/info/files/law/contribute_to_law-making/documents/e-code x-main-act-en.pdf $>$ accessed 12 January 2021. 
payment is generated automatically on the basis of batch data from the claim. However, that draft requires acceptance by an adjudicator, which is carried out by affixing an electronic signature. Only then, such an order for payment is served on the defendant. In the upcoming years - apart from the uniformization of electronic service already being implemented by public bodies - the implementation of a new clerical system is planned. That system is going to supersede the various systems hitherto in operation and then provide a comprehensive back-office service both for a court and for processes wherein the so-called clients of the judiciary take part. 
